\title{
Retrospective and futuristic idealization: Defining German coloniality after the loss of empire
}

\section{Florian Krobb}

National University of Ireland Maynooth / Universiteit Stellenbosch

\begin{abstract}
The article discusses two very different examples of German post-imperial writing as manifestations of a colonialist imaginary that was both retrospective / nostalgic and futuristic / aspirational. They serve to illustrate how colonialist discourse after 1918 shaped attitudes towards colonial space in ways that survived the next historical caesura, that of 1945. Some of the animal stories from former German East Africa assembled in Rudolf Sendke's book of reminiscences (1925) enact an idealized benevolent and respectful, yet determined and capable role of Germans in unruly and dangerous colonial space, while Adolf Kaempffer, 15 years later, devises a vision of the perfect National Socialist society based on social engineering and racial segregation to be created in an imaginary regained German South-West Africa.
\end{abstract}

\section{Keywords}

Germany, post-colonialism, post-imperialism, Third Reich, Weimar period

The very terminology of post-colonialism implies historicity. The term colonialism refers in the first instance to the historical phenomenon of the existence of overseas empires acquired and ruled by European nations; it also denotes attendant attitudes and discourses of conquest, exploitation and mastery. While the European relationship with the non-European world since the end of colonial empires (i.e. since de-colonization) up until the present day might show clear traces of colonialism, while the actors involved might display colonialist attitudes and engage in (formal and informal) practices of

\section{Corresponding author:}

Florian Krobb, School of Modern Languages, Literatures and Cultures / German, Maynooth University, County Kildare, Republic of Ireland.

Email: florian.krobb@nuim.ie 
mastery and exploitation, and while it is thus completely appropriate to speak of neocolonialism and neo-imperialism, the term colonialism itself loses its analytical value when applied to scenarios that do not fulfil the legal and political criteria of European rule over non-European territory. However, colonial culture and mentality survived decolonization. Many features of contemporary multicultural, migrant and fluid societies trace their origins back to colonial times. Many of the issues of identity formation, encounters with cultural 'others', the emergence of precarious spaces of demarcation, liminality and fluidity which originated in colonial or quasi-colonial interaction with the non-European world, continue to dominate contemporary realities and their discursive reflection, and increasingly intensified after the end of the colonial world order. While it is also completely appropriate to frame contemporary dynamics of globalism, migration and multi-, trans- and cross-culturalism, of identity formation both collective and individual, as well as dynamics of encounter, among other issues, with the help of concepts developed from colonialist contexts, such as third space, interstices, mimicry, hybridity, asymmetry and so on, these phenomena have long transcended colonial relationships in the original sense of the word, i.e. the relationship between colonial master and colonial subject. This is not to say that historical investigation in any discipline should excuse itself from the analysis of legacies from the colonial age in post-colonial scenarios. On the contrary, the importance of colonial pasts and the attendant complexities probably become even more visible in the light of their reverberations in later times.

However, contemporary German manifestations of post-colonial reflection, evident, for example, in the historical literature analysed by Dirk Göttsche (2014), are often, maybe even predominantly, geared towards the histories and legacies of coloniality. Only rarely are applications for the future, for development, engagement, co-existence, collaboration and understanding in a post- or neo-colonial global world derived from such investigations, unless in vague notions of interculturalism and respect for anything indigenous - as often expressed in popular fiction. Literary and scholarly discourses identify historical colonialist mentalities, attitudes, behaviours and practices. These investigations also identify the cultural, political and interpersonal dynamics which the European reach into the overseas world created in the affected territories on the periphery, as well as in the domestic realm, i.e. among the colonized and the colonizers alike. Furthermore, events or biographies regarded as symptomatic for the former are investigated. What this kind of discourse reacts to can be summarized as coloniality as it existed during the era of empire, its manifestations, assumptions, practices and justificatory strategies. In the aftermath of seminal manifestos such as Edward Said's Orientalism and Homi Bhabha's The Location of Culture, this kind of discourse also concentrates on identifying the implications of constructing a colonial 'other' and the intricacies of negotiating and ascribing collective and individual identities in encounters with alterity, as well as the insecurities arising from the engagement with the colonial 'other', and on knowledge and politics in the service of acquiring, consolidating and expanding dominance over colonial space. Contemporary post-colonial discourse also analyses motivations and justifications of the European reach into the overseas world as well as legacies of empire both factual (continued settlement or other engagements in the colonial realm) and mental (continued assertion of claims to superiority and the necessity of the specifically German cultural mission). 
Contemporary German post-colonial discourse in academia and in literature has demonstrated an increasing awareness of continuities that extend beyond the loss of empire. While the impact of historical caesuras - such as Germany's loss of her overseas possessions in the Treaty of Versailles - might have changed the political landscape and the course of history, these caesuras altered attitudes and mentalities to a much lesser extent. The 'development' of colonial space in the image of 'development' in Europe itself refers to the export of technological and infrastructural advances to overseas places, thereby subjecting these to European notions of 'progress', efficiency, order and usefulness (the German term Erschließung captures all of these things). From this point of view the entire period from the 1880 s well into the 1960 s can be analysed as a unified epoch, the inner rhythm of which, according to Dirk van Laak (2004: 405), followed the logic of global political, economic and technological horizons of perception. A similar view can be taken as regards mental dispositions: the colonial fantasies which straddle pre-colonial, colonial and post-colonial times. Changes in European concepts or constructions of the colonial world, their expression, their vehemence and their impact might be influenced by historical circumstances, yet subcutaneous underlying attitudes and perceptions, modalities and predispositions of colonial mentalities often resist external determination. Altered fields of engagement (developmental activity, tourism and economic interest) produce different forms of expression of very familiar sentiments. The dualism of (exoticist) attraction and (supremacist) repulsion continues to inform engagement with perceived 'others'; actions continue to veer between the poles of asserting distinction and imposing sameness in one's own European image.

Yet, continuities can only be identified when the specifics of historical conditions are properly acknowledged. German post-imperial and post-colonial discourse was widespread and differentiated; its reach stretched beyond narrow constituencies and, for example in the form of adventure fiction, influenced the attitudes of many generations in similar ways. A flood of publications of polemical, exploratory-scientific, adventurous, autobiographical and utopian-futuristic varieties, among others, participated in this shaping of the mental, imaginary landscape of German post-colonial coloniality. Only a survey of a meaningful quantity of material can distinguish phases, directions, patterns of argument and image production as well as nuances and internal differentiations in the immediate post-imperial discourse, which is still widely regarded as quite monolithic since it only lasted a little more than two decades before publication on colonial matters came to an end in 1942 after a brief last period of heightened activity (Linne, 2008: 81).

Even though Wolfe W. Schmokel's warning (1967: 22-3) not to overemphasize the importance of revisionist agitation during the Weimar years should still be heeded, it is well known that the activities of colonial associations kept colonial memory at the forefront of political debate in post-war Germany, and that they articulated misgivings concerning the stipulations of the Versailles Treaty and aspirations regarding its repeal. Furthermore, they also helped in the formation of a colonialist subculture, a milieu with youth and women's associations, rituals and memory sites which intersected with other subcultures predominantly on the conservative right on the spectrum of political and cultural persuasions. During the first years of the Third Reich, both the policies and the organizational infrastructure were increasingly subsumed (gleichgeschaltet) into the allembracing National Socialist machinery. As colonialist ideas and their protagonists' 
energies were absorbed into Nazi ideology and made subservient to the party's goals, the attendant visions of a renewed global German empire received impetus, especially during the late 1930s - when Nazi policies successfully defied other stipulations enshrined in the Treaty of Versailles and provoked the Allies into appeasing concessions.

The volume of colonialist literature that reached the market peaked in 1939-40. During that time, German visions of empire achieved a whole new intensity, urgency and quality. The German communities that remained in former colonies (mainly in German SouthWest Africa) or re-settled there (Cameroon, German East Africa) were now viewed within the parameters of the prevailing ideology and became discursively integrated into the ominous German Volksgemeinschaft as the overriding force to determine the course of history. The fact, however, that after 1941 the political and military agenda of the Nazi leadership abandoned plans for overseas expansion, and the fact that the output of related material stopped abruptly and almost completely around the same time, does not mean that the protagonists of colonial renewal had stopped dreaming, or that more immediate concerns arising from the historical situation (i.e. the change in Germany's military fortunes) had completely removed the necessity to define German identity in global, and that means colonial, dimensions. In the absence of concrete realities and of opportunities to make these realities happen, fantasy can often run even more freely, attitudes can harden, unchecked and untempered views may linger. There is, then, one commonality between 1918 and 1945 as regards the German outlook on, firstly, their formal former empire, and, secondly, Germany's collective ways of relating to the overseas world in general. This commonality is rooted in the fact that, in 1918, colonial desires and aspirations were not abandoned, but only suspended in reality while kept alive in discourse, and that around 1941, after the surge in colonialist propaganda in the wake of German successes in the war, colonial desires were rerouted towards Lebensraum in the East rather than overseas. One consequence of the German colonial lobby's inability to enact their fantasies, to implement the ideals of the National Socialist Volksgemeinschaft in colonial space, it could be argued, is that this arena became less tainted by the atrocities committed during Nazi rule: after 1918, Germany did not have the opportunity to implement racist ideas in her colonies or to commit genocide overseas, even though scenarios of strict racial separation, marginalization and disenfranchisement of indigenous populations indeed abounded before the colonial lobby had to accept that their plans for the reacquisition of former colonies and possibly others (the ominous German Middle Africa, Madagascar) had to be abandoned. German post-imperial colonialists escaped the scrutiny and accusations that the perpetrators in the colonial space of the East had to face.

The apparent absence of colonialist stirrings after 1945 cannot conceal continuities in Germany's relationship with the colonial space now rebranded 'Third World' (Laak, 2004: 366) and a continuation of remembrance of former glory - expressed, for example, in the form of veneration for surviving 'heroes' of the colonial age (see Verber, 2014). Continuities such as these might have contributed to the impression that postcoloniality did not feature prominently on the public agenda and if it did, then hesitantly, without conviction and in forms that seem alien to a more recent post-colonial agenda (Albrecht, 2008). Other factors have contributed to the complexity of the post-imperial and postcolonial discursive field in Germany since 1919. These include the aging of the protagonists and the fading of living memory of past glory, the institutionalization of their activity 
in associations which might be belittled as an assembly of nostalgic veterans, the repetitiveness of their arguments and stories, the diminishing attractiveness of youth organizations the very distinguishing features of which - the fostering of 'colonial' virtues - had been adopted by organizations from Jugendbewegung and Wandervogel to the scouts of religious and secular affiliation, and of course also by the political movements' youth organizations. An important factor is also constituted by generational dynamics: the desire of younger generations to define themselves in distinction to the older, the desire to radicalize the elder generation's positions and methods. Even though many of the protagonists of German colonial glory lived well into the post-World War II era, and while a colonial veteran, Franz Xaver von Ebb, continued to hold the powerful position as head of the NSDAP's Kolonialpolitisches Amt until the end of the war, a new generation made their voices heard around 1940 which, while acknowledging their forebears' achievements, often considered their attitudes and preoccupations irrelevant to 'progress'.

In spite of heightened sensitivities, honed by post-colonial theory and, in the German case, also by the ongoing process of Vergangenheitsbewältigung, many of the complexities, nuances, subcutaneous mentalities and attitudes as well as the imagery and rhetoric in which they found expression, have never been studied in any detail nor even remotely been evaluated in their complexity and variety - and thus many threads of continuity have not been identified. What, for example, distinguished the quintessential German colonialist in his own mind, how did he define his role and how did he keep this selfimage alive after he was deprived of his field of activity? How did, against the Allies' allegations, Germans assert their colonialist aptitude and persuade the world at large, but most importantly themselves, of their continued mission? In particular, how did Germans narrate their (former and potential) mastery of the strange and alluring yet dangerous place they laid claim to, and how did they demonstrate entitlement to it? How did colonial veterans communicate with younger generations who did not share either experience or enthusiasm for the lost territories? What legacies did the campaign of self-stylization leave and how might it have contributed to the attitudes towards the colonial overseas world of future generations? Any investigation of selected material can only ever hope to suggest some partial answers to questions such as these. The two texts chosen here illustrate very different manifestations of German post-coloniality. Though only separated by some 15 years, they very clearly reflect distinct historical stages, interests and styles of framing the colonial and from that deriving blueprints for the future.

\section{II}

Early explorers and pioneers of African penetration provided the matrix for German interaction with colonial space. They created an image of themselves, and bestowed a responsibility upon their successors, which foregrounded idealistic motifs for their engagement: the pursuit of knowledge, sacrifice and benevolence towards the inhabitants (Zantop, 1997). At the same time, they demonstrated that colonial space could be mastered - on the most basic level by simply surviving its strange and hostile environment. Through their reports they started the process of constructing a type of an ideal (German) colonialist, the traits of which later became subsumed into the icon of the 'Old African' - who combines a love for the space he operates in and its inhabitants with the 
ability to dominate it by understanding it, learning its secrets and adapting to its conditions (see Krobb, 2016b).

Like so many publications from the era, Rudolf Sendke's reminiscences of his time as a teacher at a state school in German East Africa, Aus verlorenem Sonnenland ('From the Lost Place in the Sun', 1925), comes with a seal of approval from one of the guardians of German colonial memory, namely a foreword by Heinrich Schnee, the last governor of German East Africa. Also in a quite conventional way, the book ends with a rehashing of the slogans and arguments of revanchist interests- slogans and arguments which, it has been maintained, formed a consensus across a wide political spectrum in Weimar Germany, only excluding the far political left, but including, for slightly different reasons, the entirety of the so-called Weimar coalition of moderate parties of the left, right and centre. These slogans and arguments, mainly concerning the necessity of colonies as suppliers of raw materials and food, as receptacles for the alleged population surplus and as a field to direct the energies of younger German generations, and also concerning the suitability of Germans as colonizers, allegedly evidenced by the natives' love and respect for their masters ('Der Neger liebte uns' ('The negro loved us'); Sendke, 1925: 232), culminate in the common battle cry: 'Deutsche Jugend, vergiß nicht, was man uns alles diebisch geraubt ... Vergiß nicht, daß man unserem Volkskörper Arme und Beine abgehackt hat und den Rumpf elend verbluten läßt' (Sendke, 1925: 234). (German youth, never forget what thieves have stolen from us. Never forget that arms and legs were chopped off the body of our nation and the rump was left to bleed to death.)

The anecdotes and sketches assembled in the book are designed as reminders of what kind of memory is to be kept alive: in particular the memory of a specific kind of engagement with colonial space needs to be preserved for when the colonies are restored. The book defines colonial space as one impregnated by German influence and promotes a pronounced German mode of engaging with it. The work's subtitle, Charakter-, Tierund Jagdbilder, reveals an attempt to appeal to a wide and young audience and to reach a readership that might not be interested in serious revanchist campaigning. The title is reminiscent of nineteenth-century genre pictures which responded to a middle-class desire to combine edification with instruction. The element of instruction is represented here by lengthy but light-hearted explanations regarding the fauna of German East Africa. The anecdotal style of the narrative provides entertainment and also contributes to the educational impact, since many of the episodes contain moral messages which highlight aspects of interacting with the African environment: of coping with, surviving and building a productive relationship. The book is quite obviously aimed at instilling in its readers a benevolent attitude towards colonial space while concurrently recreating some of the excitement of living in the continent's exotic environment.

A large section is devoted to everyday life, natural conditions, diseases and ways of coping with such conditions, as well as to the treatment of indigenous people (including the use of corporal punishment of natives and their tolerance, even appreciation of such 'educational' measures and their strategies of evasion). The majority of the book's chapters, however, bear the names of wild African animals as titles. Sendke employs the revealing strategy of concurrently emphasizing and appropriating the exotic by combining in his headings the German name of the animal with its indigenous name: 'Simba, der Löwe' (lion), 'Kiboko, das Flußpferd' (hippopotamus), etc. These titles are intermingled 
with chapters on individual rather than generic animals: for example, 'Hänschen, die Geschichte eines afrikanischen Fischotters' (Little Johnny, the story of an African otter). This technique highlights the strategy of concurrently emphasizing the strange, wild and potentially dangerous nature of the beasts, but most certainly their belonging to and representativeness of Africa. At the same time, by transforming a Swahili term into a pet name, it represents an act of appropriation and domestication.

Two examples shall suffice to illustrate the potential of animal stories to negotiate the German colonialist's attitude and behaviour towards the indigenous. Through staging different encounters with animals, displaying different attitudes towards the wild fauna of East Africa and illustrating a variety of approaches by a variety of European characters to them, Sendke defines, for himself, the successful German 'African' in general and, for new generations, their place on a complex grid of colonial behaviour - one that might provide a sustainable blueprint for future engagement. The design of the book indicates a programmatic ambition: these sketches are aimed at Africa, and the Germans' relationship with it, as a whole. Consequently, the book opens with a chapter on the most iconic representative of African nature - the lion as potential rival for mastery of the natural environment, as potential challenger of European superiority - and therefore the most coveted trophy of European hunters. Via interaction with animals, be it by studying them, keeping them, capturing them for European zoos or by hunting the most dangerous among them for pleasure or protection, the colonialist staged his relationship with the continent as a whole (Krobb, 2013). At the outset, Sendke paints a seemingly contradictory picture: on the one hand, he describes the iconic image of the majestic beast, sitting on a termite hill in sharp silhouette against the setting sun; on the other hand, he captures the scene of an exhausted and hungry pride trotting next to a dusty road. The former image is one of self-sufficiency: here, the icon of the indigenous is cast as the master of all he surveys, elevated and unfazed by the presence of humans. Africa is thus ascribed not only majesty (even sublimity), but self-sufficiency. The European remains an onlooker, his interference is not necessary. The latter is one of destitution, volatility and victimhood: here, Africa offers not only the scope for European interference, but bestows a responsibility - yet it is interference of a specific kind, based on an clear-sighted, sympathetic, immersive, knowledgeable and pro-active stance that Germans ascribe to themselves. The majestic animal is, if not entrusted to his care, then object of his sympathy and compassion. The subsequent narrative populates the field of engagement and selfpositioning outlined by this very matrix.

After some very brief sentences about a lion's habitat and characteristics, Sendke assumes the attitude of someone who is entrusted with the well-being of the land he inhabits by accepting his responsibility to defend the land against the 'Landplage' (menace) that endangers the safety of humans (Sendke, 1925: 1-2, 10). He relates the experience of a fellow German who had to defend his livelihood and the well-being of his native subalterns against intrusion: 'Die Löwen wurden frecher und hatten sich aus dem Viehkral ... einen Ochsen geholt.' (Sendke, 1925: 6) (The lions became bolder and had taken an ox from the enclosure.) Even though the threat to humans posed by hungry wild predators motivates this story, the animals are exculpated; the responsibility of coping with the situation is firmly ascribed to the humans. Hence other episodes concern human failings in their interactions with the wild. These episodes relate how boastful new 
arrivals have their photos taken in a victorious pose in front of stuffed animals, how a clumsy young man gets stuck in an iron trap and loses his leg, and how even experienced lion hunters fall victim to the lion's cunning.

Sendke's narrative thus stages a trial of strength between human and animal, between 'civilization' and the nature he aims to understand and master. The contest has different outcomes - the gesture of graciously granting, in his selection of stories, the indigenous partial and temporary victories, is in itself significant in that it exhibits respect for the indigenous. When, for example, the author relates that on a lion hunt he spent the night unaware of imminent danger yet failed to achieve his aim as the lions got away (Sendke, 1925: 26-7), he suggests a certain stalemate, or equilibrium. The tension between African unpredictability and the familiarity generated by the anecdotal form of the narrative, by the personalization of experience, by humour and similar devices, avoids coarse fantasies of subjugation - rather it stages a vision of acceptance and equitable co-existence. Thus Sendke defines one of the essential characteristics that Germans ascribed to themselves: respect for the desired terroir as the condition for survival and mastery. The description of indigenous helpers' involvement in the various scenarios ascribes significant roles to them: for example, they offer assistance and willingly subordinate themselves to the leadership of the whites. In that role they display skill or clumsiness, i.e. are exempt to a degree from stereotyping: after successful hunts they show gratitude for the protection received and on one occasion they utilize the melted fat from the lions' carcasses to produce miracle potions and ointments. All of this stages the blueprint for harmonious co-existence, from division of labour to mutually complementary exploitation of indigenous resources.

There is one episode, though, that focuses exclusively on the narrator and his feline opposite. He tries to capture a lion with the help of bait and a trap (tokens of technological superiority and deliberate planning) and settles down to observe his contraptions from the safety of an artificial hole in the ground (an act of immersion in the colonial soil, almost of inverted mimicry); yet in a gesture that supplants the lion's majestic posture, he assumes the position of master of what he surveys: 'Nach vorn hatte ich freie Bahn, so daß ich alles bequem überblicken konnte' (Sendke, 1925: 20) (To the front, I had a clear line of sight so that I could comfortably survey everything). When lions actually appear, he shoots at them, but leaves the verification of his hunting success until the next morning. Instead he lights his pipe and helps himself to a bottle of well-chilled beer before falling asleep in his dugout. The accommodation with the indigenous and the maintenance of European standards of comfort are reconciled, the violence of confrontation is smoothed over and the secret of colonial success is attributed to equanimity. Yet in the de-heroicization of the protagonist and the ostensible normalization of co-existence, the German colonialist constructs himself as equal to the task of mastering Africa, even as predestined.

Another striking example of how the author uses animals as a metaphor for his European approach to the indigenous is contained in the story of 'Hänschen, die Geschichte eines afrikanischen Fischotters'. Here the narrative illustrates how domestication amounts to a taming of the 'wildness' of the indigenous through targeted nurturing measures, reward and punishment, and through sheer habit. The success justifies the means: 
Mit der allmählichen Gewöhnung an gekochte Nahrung hatte Hänschen alle Wildheit abgelegt und war nach und nach ganz zahm geworden. Bei meinen Mahlzeiten saß der Otter neben meinem Stuhl und wartete auf den ersten Brocken, den ich ihm gab. Zögerte ich, so pfiff er und kratzte mich leise mit seinem Fuß. (Sendke, 1925: 56)

With gradual habitualization to cooked food Hänschen had shed all his wildness and, over time, had become completely tame. At mealtimes he sat beside my chair and waited for the first crumb that I would give him. If I delayed, he whistled and gently scratched my foot.

The process of 'taming', of domesticating the wild creature and thereby integrating it into a structure which the European identifies with 'civilization', extends to measures of discipline that the narrator introduces with an apologetic gesture which casts him as a reluctant master:

Manchmal war ich genötigt, meinen kleinen vierbeinigen Freund wegen irgendeiner Unart zu bestrafen. Ich nahm dazu eine Peitsche und zog ihm ein paar Hiebe über. Er legte sich dann auf den Rücken, hielt sich mit seinen breiten Vorderschwimmfüßen die Augen zu ... und kreischte, fast möchte ich sagen weinte, wie ein Kind. Aber nachträgerisch war er nicht. Sofort kam er folgsam wieder zu mir, kletterte auf meinen Schoß und ließ sich streicheln und liebkosen. (Sendke, 1925: 59)

Occasionally I was obliged to punish my little four-legged friend for some misdemeanour. For that purpose I used a whip and gave him a few lashes. He rolled on to his back, covered his eyes with his broad front paws and shrieked, one could almost say cried, like a child. But he did not hold a grudge. Obediently he came back to me, climbed onto my lap and allowed me to stroke and caress him.

In spite of the apologetic introduction, this account amounts to a fantasy of almost total power and control over the indigenous - achieved by a combination of castigation and affection, mirrored in other relationships with inanimate nature and with humans. Episodes like this foreshadow the treatment of indigenous people that is discussed in the chapter 'Erziehungsmittel (Strafen)' ('Educational Measures (Punishments')) (Sendke, 1925: 194-200). Domestication effects a loss of indigenous skill and traditional ways of interacting with the environment. The tame otter gets lost in the lake and has to be rescued. That in both stages of this episode indigenous helpers are involved - as negligent guardians of the pet and as able retrievers - extends the role allocation to domesticated subalterns by casting them as both undisciplined 'savages' and as the agents of order, stability and security. As the former, they require guidance; as the latter, they are welcomed as allies in the German colonial project.

In the analogous sphere of natural history, Sendke thus stages the very dynamic and logic of colonial relationships as a whole. The reminiscences of the schoolmaster illustrate how Germans have shouldered their responsibility and signal to new generations that they are capable of doing the same - a message even more powerful since it is not proposed by an administrator or a plantation owner with commercial interest, and since it is not expressed in a narrative of crude heroism, but in a gentle, anecdotal and often light-hearted way. Reassuming colonial 'responsibility' is styled for the benefit of 
juvenile readers as an adventure, a duty and a rewarding challenge. The episodes related here are offered as representative of the alleged successes of German colonialism in general and as reminders of the ways of achieving these. The impact of books like Sendke's is based on the ability to cast colonial space as a playground. Challenges and adversity are not denied, but smoothed and diluted - rendered not only endurable but enticing. Removed, as they seemed to be, from burning political controversies, such books contributed to the formation of a colonial subconscious in young readers that could be sustained independently of any colonial reality since its construction is shifted onto uncontroversial ground (animal husbandry). Yet it sustains desire - to hunt a lion and tame an otter - and it promotes the mission that young readers fulfil their role in overseas territory in that very vein.

\section{III}

Quite a different understanding of the Germans' role in colonial space is represented by Adolf Kaempffer's novel Das erste Jahr ('The First Year', 1940). This book, a utopian novel set in a South-West Africa that has been returned to Germany, is part of a wave of publications which, in the wake of the success of Hans Grimm's Volk ohne Raum ("A People Without Space', 1926) drew attention to the alleged plight of Germans in SouthWest Africa under the occupational rule of the Union of South Africa which had been granted the mandate by the League of Nations.

In the post-imperial German imagination, the former German South-West Africa enjoyed quite a different status from the other former protectorates, including the jewel in the crown, East Africa. The quick defeat of the German troops (their surrender took place in early July 1915) did not lend itself to glorification: the land with its deserts forbade exoticist fantasies of tropical lushness. But it was inhabited by the largest German settler community, the majority of whom escaped dispossession and eviction after the seizure of the colony, as happened in other African colonies. This situation gave rise to concerns about the fate of German identity under foreign rule, an area that contained echoes of debates surrounding emigration and the assimilation of German settler populations into their North and South American host societies since the early nineteenth century. A lot of attention has been devoted to some of the literature of and about German South-West Africa (the most comprehensive but by no means complete bibliography is in Keil, 2003), particularly since the two best-selling colonial novels of all time, Gustav Frenssen's Peter Moors Fahrt nach Südwest ('Peter Moor's Journey to the South-West', 1906) and Hans Grimm's Volk ohne Raum, deal with this territory and the two great caesuras of its history, namely the Herero War and the events of the First World War respectively (see Brehl, 2004; Gümbel, 2000; Hermes, 2009). However, the sheer breadth and variety of the discourse of self-positioning, relating to the indigenous environment, and reflection of the issues pertaining to mandate rule, have not yet been studied comprehensively (a provisional systematic evaluation is attempted in Krobb, 2016a). After around 1935, attempts to ingratiate themselves with the Nazis are perceptible in memoirs and fiction about South-West Africa, i.e. the authors seem to be paying lip-service to the new regime and its ideology as possible supporters of their desire to assert their Germanness under Mandate rule. The majority of domestic German publications, though, forcefully 
promoted National Socialism and used the attendant rhetoric, sloganeering and sentiment with conviction. Kaempffer's Das erste Jahr represents a narrative that seems completely in tune with National Socialist designs for the administration and integration of colonial space into an all-German empire. (Hermes (2011) erroneously ascribes only moderate traces of Nazi ideology in Kaempffer's novels.) The novel amounts to a fictitious blueprint for future colonialism: its protagonist, an extreme actualization of the myth of the engineer as epitome of colonial modernity (Laak, 2004: 243-5), is portrayed as a role model for NS-inspired activity in colonial space and, at the same time, as a personification of the virtues of the glorified global German Volksgemeinschaft.

What characterizes Kaempfer's vision of 'colonial hypermodernity' (Hermes, 2011: 261) and visions of technological omnipotence (Schneider, 2011: 277) is that it outlines the imposition of ideas, and the implementation of policies and measures, that are fundamentally divorced from any exoticism and also from any attempt to revive the colonial glory of old. The remarks on the splendour of the steppe are half-hearted derivatives of stereotypical tropes; the romanticism of the sparseness, emptiness and vastness of the landscape is supplanted by the vision of a densely populated, lush and well-connected settlement (railway links obviously form part of the design) that 'differs from a large German village or agrarian town only because of the heat and because of surroundings that will, at least at first, still appear strange' (Kaempffer, 1940: 367). Any exotic 'strangeness' is supplanted by a domestic vision: the implementation of an ideal community infused with the National Socialist ideology of blood and soil:

jeder Bewohner des Dorfes [soll] mindestens drei Hektar Land selbst bewirtschaften ... um auf diese Weise die innere Verbundenheit mit dem Geschick der Siedlung zu erlangen, zu der er nicht kommen würde, wenn er sich auf seinen gewerblichen oder beamteten Beruf beschränkte. Sind aber der Lehrer, der Postbeamte, der Gemeindevorsteher, der Ortsgruppenleiter und der Pastor gleichzeitig Siedler und Bauern wie die anderen auch, dann stehen sie fest und mit vollem Verständnis für ihr Wohl und Wehe in der Gemeinschaft. (Kaempffer, 1940: 254)

Every inhabitant of the village is to cultivate at least three hectares of land so as to thereby develop an inner connection to the fate of the settlement which would not be achieved if they concentrated on their profession in the civil service or the trades. If teachers, postmen, elders, leaders of the local party organization and vicars also become settlers and farmers, they will be rooted in and appreciative of the joys and woes of the community.

Colonial space is to be stripped completely of its specificity and subsumed into an allembracing völkisch organism. While Sendke acknowledged, at least partially, an Africa independent of German making, and sought an accommodation with the indigenous (though on his terms), Africa and non-white Africans in Kaempffer have ceased to exist as independent entities. In some respects, Kaempffer's designs form a continuation of policies from the colonial era itself, for example with regard to proto-Apartheid bans on intermarriage and the creation of a homogeneous, universally available and totally controlled indigenous workforce regardless of cultural, ethnic and regional diversity (see Zimmerer, 2003: 36); in other respects, for example with regard to the place of the colonial economy in an autarchic national German economy, they are completely owed to National Socialist ideologies of the Volksstaat. 
This extends to the African workforce that is required to complete the ambitious dambuilding project in the middle of the Namib Desert. Based on the principle of 'clear and orderly arrangements for the separation of Whites and Blacks' (Kaempffer, 1940: 307), the treatment of indigenous labour amounts to a commodification of this indigenous 'resource', and their deployment shows signs of social engineering. This can provide a comparative foil to Sendke's efforts to domesticate his symbol of the African autochthonous, the otter with the diminutive German pet name Hänschen. Some explanations made by the protagonist, the engineer Flughardt, amount to a manual for the 'handling' of natives akin to guidelines for the operation of machinery, the acquisition of building materials or supplies - their 'deployment' stands metonymically for the 'operation' of Africa as a whole. Not only is the white builder 'taking delivery' of the workforce recruited elsewhere and 'shipped' to their place of deployment (Kaempffer, 1940: 268), the efficient management of it in situ is defined as the foremost responsibility of the colonial master: 'Die Arbeitskaft des Schwarzen stellte einen der wichtigsten Aktivposten des größten Teils der Kolonien dar. Sie auf erfolgreiche Art zum Einsatz zu bringen, war die vornehmste Aufgabe des Kolonialpioniers' (Kaempffer, 1940: 293). (The labour of the Blacks formed one of the most important assets in most of the colonies. To utilize it successfully was the foremost duty of the colonial pioneer.) The justification is derived from a racist analysis whereby the Africans' alleged failure to take responsibility for their own well-being, or to contribute something to global culture and civilization (of course as defined by Europeans) has allocated him a subaltern place on the ladder of development and privilege. As such, the African requires 'leitende Fürsorge' (caring guidance) (Kaempffer, 1940: 294), outlined here as an act of social engineering:

Wir werden dem Schwarzen eine Entwicklungsmöglichkeit geben, in deren Verlauf wir ihn von Stufe zu Stufe beobachten und leiten, aber auch nicht einen Augenblick zögern werden, ihn in seine Schranken zu verweisen, wo es not tut. Denn er soll an der Entwicklung den Anteil haben, den wir ihm kraft unserer höheren Erkenntnis nach seinen Gaben bestimmen. (Kaempffer, 1940: 298)

We will grant the Blacks an opportunity for development, in the course of which we will observe and guide them. But we will not hesitate for a moment to put them in their place, if necessary. The Black is designated to participate in a development that we, thanks to our superior insight, determine according to his talents.

The rhetoric of gradual 'development' cannot conceal the complete objectification of the Africans. African conditions, regarding the natural environment and the autochthonous population, are considered exclusively in terms of opportunity or hindrance to the implementation of a fascist vision or utopia (Schneider, 2011: 254); colonial science and technology, and even the experience of veteran colonists (the 'old Africans' hailed so much in earlier literature), are reduced to tools for overcoming the obstacles posed by indigenous conditions and to take advantage of their opportunities. In this respect, the text conveys the impression that it is only coincidentally set in the German protectorate; similar scenarios could, with minute alterations, be transplanted into the Lebensraum (to be) acquired in Eastern Europe where the local Slav population - also deemed racially inferior and incapable of self-governance - would substitute for the African workforce in this 
narrative. While ostensibly continuing the revanchist tradition of the Weimar years with its strong retrospective mode of argumentation, Kaempffer's narrative amounts to a damnatio memoriae of colonialist nostalgia. The sedentary white population of cattle farmers is moved sideways, their concerns and experiences are silenced and their relationship with the land - the stuff of immediate post-imperial myth - is rendered irrelevant. In this vision, Africa has ceased to exist - be it white or black, be it animate or inanimate.

\section{IV}

A prominent motif in the writing of early exploration and the German 'mission' in Africa in popular literature was that of 'gifting Africa to herself' - i.e. through German guidance, creating an African awareness of herself, her history and her potential (see Krobb, 2014). This thread was superseded after the acquisition of actual protectorates by different discourses of penetration, development and exploitation. The notion of tutelage evoked in both Sendke and Kaempffer, but to different effect - emerged from the original mission, but from the outset this concept implied an external determination of the direction that guidance should take and thereby legitimized colonial zeal. In post-imperial writing, Africa is totally subjected to German projections. What Sendke and Kaempffer have in common is that none of their visions have a counterpoint in contemporary reality. Whether Sendke's East Africa was ever the way he painted it, and whether Kaempffer's South-West Africa could ever become the way he envisioned it, remains irrelevant and inconsequential - none of these portrayals have to subject themselves to any form of verification. In this respect, retrospective and futuristic fantasies enjoy the same freedom. While actual revanchist propaganda waned somewhat after the mid 1920s, as the immediate memory faded and overseas trade with products from the southern hemisphere as well as 'colonial science' flourished even in the absence of actual colonial possessions (Stoecker, 2007), the production of images continued apace and engrained a distinct image of Africa in a collective mentality as well as the way the continent's inhabitants should be treated. But while Sendke derived his vision from his experience (prejudiced and one-sided as it might have been), from encounter and interaction, Kaempffer constructed his utopia from external factors which had nothing whatsoever to do with Africa, not even a skewed perception of this colonial space.

What, then, is the legacy of post-imperial writing on colonial matters, be it retrospective or futuristic? Of course, the ideological underpinnings of Kaempffer's colonialist project were utterly discredited after the end of World War II; the vision of a white African community of mutuality, efficiency, self-sufficiency and surplus (an idealized Volksgemeinschaft out of area) was untenable after 1945 for the two reasons that it excluded natives and any other non-Germans and because its raison d'être was its integration into and economic contribution to a global German community. Yet the ideals invoked to bring this vision about - planning and efficiency thorough scientific assessment of the opportunities and dangers - were not discredited, since these qualities could be abstracted from the ideology and politics that had driven them. These qualities can be regarded as 'hypermodern' extensions of the established practices of surveying, marking, ordering and impregnating colonial space. These practices had persisted since the first systematic encounters with the overseas world, i.e. encounters under the auspices of 
European modernity and scientific rationale which - while pre-modern conquerors conceived of the newly discovered space as an extension of their own Christian universe, serving the exclusive purpose of being integrated into it - could only perceive of the new territory in terms of measurement, taxonomy and absorption into the logic and archive of European knowledge. Furthermore, when divorced from their colonialist context and their revanchist purpose, Sendke's qualities of empathy, humour, respect and benevolence would not have been regarded as compromised at all.

The two examples discussed here represent contradictory and complementary elements of a complex memory field that cannot be reduced to its 'revanchist' impetus, but conveys and perpetuates attitudes towards colonial space that transcend the specific historical circumstances in which they are located. As political circumstances changed, certain elements of the memory field that had accumulated over time needed to be suppressed; others, however, had the chance to flourish since they did not fall victim to guilt complexes, altered sensitivities and specific patterns of discourse. For example, even though after 1945 the view that, by virtue of their understanding, benevolent, sympathetic, intimate and gentle attitude towards the strange and potentially hostile, Germans 'belonged' in and could claim 'ownership' of East Africa was no longer tenable, not even theoretically, virtues as espoused in both strands of the discourse, i.e. the notions of empathy, concern, immersion and benevolence on the one hand, and of systematic planning and economic efficacy on the other, were not compromised by either their utilization for revanchist propaganda between 1918 and 1933 nor their subsumption into Nazi designs of global domination or 'Erdraumplanung' - to adopt a term from a travelogue of 1939 that firmly holds the party line on Germany as a global power (Diel, 1939: 259).

The field of early post-imperial colonial memory is anything but monolithic. There is no master narrative, in spite of a unity of aims (the reversal of the so-called dictate of Versailles) or, in the public agitation and the mechanisms that unified the revanchist, or colonial-nostalgic milieu, in spite of a certain sense of common purpose. But, in reality, this field was complex, contested and tremendously crowded, like the field on the right of the political spectrum between revolutionary völkisch conservatism and fascism in general. The differences, of which only very few could be identified here, vary according to the generation, the actual protectorate, the text form (other media of course populated the field), the degree of familiarity and the ideological position of the contributors to the debate. Even the addressees shift. Initially a two-fold impact is intended: books of reminiscences served as reminders of shared convictions and experiences and thereby helped to strengthen a sense of identity of the remaining German population in former overseas protectorates as well as the domestic community of expellees; on the other hand, they provided arguments for the restoration of possessions and the claim to an uninterrupted, unimpaired and uncompromised German mission overseas in the political arena. As a new generation raised their voices, the concerns in the traditional colonialist milieu faded, and the diplomatic and political fight against the stipulations of Versailles and the various British, French and South African mandate regimes was supplanted by visions of global German dominance as it was to manifest itself in colonial space. The addressee had now become the leadership of the Third Reich; colonial agitation in fact and fiction now served the purpose of expediting the reinstatement of colonies as a matter of course, and the implementation of an ideal society in territory that was, again, declared to be in 
urgent need of German governance. Any attempt at immersion in African culture, any light-heartedness of approach and humorous representation of the splendours and absurdities of European life in Africa, any even remotely joyful attitude towards Africa is completely absent in Kaempffer - and many of his contemporaries as well.

And yet, one underlying notion connects the discourses of the 1920s to early 1940s - a notion that was derived from pre-colonial fantasies, sustained through the period of colonization itself and, after the immediate shattering of all colonial aspirations (which set in when German military fortunes changes in 1942-3), a notion that had the potential to be revived in fundamentally changed political circumstances, a notion that afforded both the Federal Republic and the GDR the chance of renewed engagement and informs developmental cooperation to this day (on the continuities between colonialist and developmental engagement in areas such as conservation see Michels, 2008: 194-6) - this notion is the simple common denominator that 'Germans know best'.

\section{References}

Albrecht M (2008) 'Europa ist nicht die Welt': (Post)Kolonialismus in Literatur und Geschichte der westdeutschen Nachkriegszeit. Bielefeld: Aisthesis.

Brehl M (2004) 'Das Drama spielt sich auf der dunklen Bühne des Sandfeldes ab': Die Vernichtung der Herero und Nama in der deutschen (Populär-) Literatur. In: J Zimmerer and J Zeller (eds) Völkermord in Deutsch-Südwestafrika: Der Kolonialkrieg (1904-1908) in Namibia und seine Folgen, 2nd edn. Berlin: Links, pp. 86-96.

Diel L (1939) Die Kolonien warten! Afrika im Umbruch. Leipzig: List.

Göttsche D (2014) Remembering Africa: The Rediscovery of Colonialism in Contemporary German Literature. Rochester, NY: Camden House.

Gümbel A (2000) Instrumentalisierte Erinnerung an den Ersten Weltkrieg: Hans Grimms 'Volk ohne Raum'. In: H Berding, K Hellern and W Speitkamp (eds) Krieg und Erinnerung: Fallstudien zum 19. und 20. Jahrhundert. Göttingen: Vandenhoeck \& Ruprecht, pp. 93-111.

Hermes S (2009) 'Fahrten nach Südwest': Die Kolonialkriege gegen die Herero und Nama in der deutschen Literatur (1904-2004). Würzburg: Königshausen \& Neumann, pp. 45-87.

Hermes S (2011) 'Leere Räume' - 'Treue Neger': Der literarische Kolonialrevanchismus im 'Dritten Reich'. In: O Gutjahr and S Hermes (eds) Maskeraden des (Post-)Kolonialismus: Verschattete Repräsentationen 'der Anderen' in der deutschsprachigen Literatur und im Film. Würzburg: Königshausen \& Neumann, pp. 241-69.

Kaempffer A (1940) Das erste Jahr: Roman des kolonialen Morgen. Braunschweig: Westermann.

Keil T (2003) Die postkoloniale deutsche Literatur in Namibia (1920-2000). PhD thesis, University of Stuttgart.

Krobb F (2013) 'Den Sudan erobern': Zu diskursiven Kontexten und kolonialistischen Implikationen von Karl Mays Sudan-Erzählungen: das Beispiel der Großwildjagd. Jahrbuch der Karl-May-Gesellschaft, pp. 251-73.

Krobb F (2014) Family reunions in German adventure literature on Africa of the 1880s. A vision for colonial intervention: Karl Burmann and Karl May. German Life and Letters 67: 301-19.

Krobb F (2016a) Der deutsche Krieg in Südwest: Zur Verknüpfung von Kolonialismus- und Erinnerungsnarrativen nach 1918. Acta Germanica 44: 127-43.

Krobb F (2016b) 'Imitierte Mohren': 'Alte Afrikaner' und reziproke Mimikryverhältnisse im deutschen Afrika-Schrifttum. In: $\mathrm{C}$ de Gemeaux and C Repussard (eds) 'Civiliser' le monde, 'ensauvager' l'Europe? Circulations des savoirs, transferts et 'mimicry' dans l'espace germanophone et sa sphère coloniale. Paris: Le Manuscrit, pp. 305-32. 
Laak D van (2004) Imperiale Infrastruktur: Deutsche Planungen für eine Erschließung Afrikas 1880 bis 1960. Paderborn: Schoeningh.

Linne K (2008) Deutschland jenseits des Äquator: Die NS-Kolonialplanungen für Afrika. Berlin: Links.

Michels S (2008) Treue Askari - gefürchtete German soldiers: (Erinnerungs-)Politische Grenzüberschreitungen. In: W Speitkamp (ed.) Erinnerungsräume und Wissenstransfer: Beitäge zur afrikanischen Geschichte. Göttingen: V\&R Unipress, pp. 171-96.

Schmokel WW (1967) Der Traum vom Reich: Der deutsche Kolonialismus zwischen 1919 und 1945. Gütersloh: Mohr.

Schneider D (2011) Identität und Ordnung: Entwürfe des 'Eigenen' und 'Fremden' im deutschen Kolonial- und Afrikaromanen von 1889 bis 1952. Bielefeld: Aisthesis.

Sendke R (1925) Aus verlorenem Sonnenland: Charakter-, Tier- und Jagdbilder aus DeutschOstafrika. Fulda: Fuldaer Actiendruckerei.

Stoecker H (2007) The advancement of African studies in Berlin by the 'Deutsche Forschungsgemeinschaft', 1920-1945. In: H Tilley (ed.) Ordering Africa: Anthropology, European Imperialism and the Politics of Knowledge. Manchester: Manchester University Press, pp. 67-94.

Verber J (2014) Remembering at a time of forgetting: Weimar colonialism in West Germany. In: F Krobb and E Martin (eds) Weimar Colonialism: Discourses and Legacies of Post-Imperialism in Germany after 1918. Bielefeld: Aisthesis, pp. 209-27.

Zimmerer J (2003): Der koloniale Musterstaat? Rassentrennung, Arbeitszwang und totale Kontrolle in Deutsch-Südwestafrika. In: J Zimmerer and J Zeller (eds) Völkermord in Deutsch-Südwestafrika: Der Kolonialkrieg (1904-1908) in Namibia und seine Folgen. Berlin: Links, pp. 26-41.

Zantop S (1997) Colonial Fantasies: Conquest, Family and Nation in Precolonial Germany, 1770-1870. Durham, NC: Duke University Press.

\section{Author biography}

Florian Krobb is Professor of German at National University of Ireland Maynooth and Extraordinary Professor at the University of Stellenbosch, South Africa. His more recent research focuses on the German discourse of Africa during Germany's 'African Century', 1840-1940. 